\title{
Nano Formulations and Inducer Chemicals contains Antimicrobial Property against Alternaria Leaf Blight of Potato
}

\author{
Jayashree Bhattacharjee ${ }^{1 *}$, Abhinandita Sahoo ${ }^{1}$, \\ Debashre Bhattacharjee ${ }^{2}$ and Amitava Basu ${ }^{1}$ \\ ${ }^{1}$ Department of Plant Pathology, BCKV, West Bengal, India \\ ${ }^{2}$ MULLaRP, ICAR Research Complex for NEH Region, Tripura centre, Lembuchrera, \\ Tripura-799 210, India \\ *Corresponding author
}

\section{A B S T R A C T}

\begin{tabular}{|c|c|}
\hline & tuberosum) is one of mankind's most valuable food crops in the world. \\
\hline Keywords & $\begin{array}{l}\text { Potato crops are affected by a large number of foliar diseases. Among them, Alternaria leaf } \\
\text { spot of potato (Alternaria solani) most important diseases causing heavy yield losses. }\end{array}$ \\
\hline $\begin{array}{l}\text { Nano formulation, } \\
\text { Fungal-pathogen, } \\
\text { Potato crop, } \\
\text { Mycelial growth. }\end{array}$ & $\begin{array}{l}\text { Hence, in the present investigation, an efficient and potential modern approach through } \\
\text { research studies was carried out related to management of agriculturally important } \\
\text { pathogens of potato crop. Under In vitro study, Seven chemicals namely Silver- } \\
\text { Nanoparticle (AgNPs), } \mathrm{AgNO}_{3} \text {, Silvox }\left(\mathrm{H}_{2} \mathrm{O}_{2}+\mathrm{AgNO}_{3}\right) \text {, Chitosan, Salicylic acid, } \mathrm{H}_{2} \mathrm{O}_{2} \text { and }\end{array}$ \\
\hline Article Info & $\begin{array}{l}\text { Isoprothiolane (Check Chemical) were evaluated in different concentrations against fungal } \\
\text { pathogen Alternaria solani under in-vitro and in-vivo condition. Out of seven chemicals so }\end{array}$ \\
\hline $\begin{array}{l}\text { Accepted: } \\
28 \text { October } 2017 \\
\text { Available Online: } \\
10 \text { December } 2017\end{array}$ & $\begin{array}{l}\text { far tested under in-vitro study, } \mathrm{AgNO}_{3} @ 10.7 \text { ppm appeared to be most effective in } \\
\text { respect of mycelia growth inhibition against Alternaria solani. The } \mathrm{H}_{2} \mathrm{O}_{2} \text { and Salicylic acid } \\
\text { exhibited maximum disease suppression due to prophylactic use at } 50 \text { ppm concentration } \\
\left(\mathrm{H}_{2} \mathrm{O}_{2}-72.74 \% \text { and Salicylic acid }-78.96 \%\right) \text { as compared to check chemical Isoprothiolane } \\
(54.54 \% \text { at } 50 \mathrm{ppm}) \text {. }\end{array}$ \\
\hline
\end{tabular}

\section{Introduction}

Potato (Solanum tuberosum) is one of mankind's most valuable food crops in the world (FAO, 2004). Potato consumption is next to rice and wheat in the world. Potato ranks fourth in global food crop production (Luck et al., 2011). The importance of potato as a food crop was duly recognized soon after its introduction in Europe during $16^{\text {th }}$ century. In the third world countries, potato could be the future food crop for the millions. Potato grows well in cold climates during frost-free seasons. It does not perform well in heat (Hijmans, 2003). Potatoes are susceptible to a number of diseases caused by fungi, bacteria, and viruses. Nowadays, foliar diseases are of great concern in potato production throughout India. Among them, early blight due to Alternaria spp. is worldwide in distribution and is one of the most serious foliage diseases in areas with favourable weather conditions (CIP, 1996). Early blight occurs in all potato production areas, but this have significant impact on the yield and quality of the tuber only during warm and, wet conditions in the cropping season when the pathogens multiply quickly and the disease spread rapidly 
(Hausladen and Leiminger, 2007). The potential applications of nanomaterial, inducer chemicals and new systemic fungicides in crop protection helps in the development of efficient strategies for the ecofriendly management of plant pathogens under sustainable agriculture. In recent years, nanotechnology has been increasingly applied to the development of novel antimicrobials for the management of pathogenic bacteria affecting agricultural crops, humans and animals. Over the past decade, a number of patents and products incorporating nanomaterials into agricultural practices (e.g., nano pesticides, nano fertilizers, and nano sensors) have been developed. A number of different types of induced resistance have been defined based on differences in signalling pathways and spectra of effectiveness, including systemic resistance and induced systemic resistance. Such resistance can be induced in plants by application of a variety of biotic and abiotic agents. The resulting resistance tends to be broad-spectrum having long lasting, effect for disease by between 20 and $85 \%$. Although research in this area has been increased over last few years. Our understanding of the impact of these influences on the expression of induced resistance is still poor. There have also been a number of studies in recent years aimed at understanding of how best to use induced resistance along with nanoformulations in practical crop proctection.

\section{Materials and Methods}

Entire experiment was conducted in Bidhan Chandra Krishi Viswavidyalaya (Department of Plant Pathology).

\section{Culture media}

Potato-dextrose-agar (PDA) medium was used for isolation of fungus like Alternaria solani.

\section{Identification of the fungal culture}

Morphological and cultural characters of isolated fungi was recorded and compared with standard text for establishing their identity (Booth and Sutton, 1984; Chowdhry, et al., 2000)

\section{In-vitro assessment of chemicals using poisoned food technique}

Potato dextrose agar amended with different nano formulation, plant inducer, ROS molecule and the final concentration of different nano formulations, ROS molecules and plant inducer are $1 \mathrm{ppm}, 5 \mathrm{ppm}, 10 \mathrm{ppm}$, 15 ppm, $20 \mathrm{ppm}$ and control.

The control is amended with sterile distilled water without any formulation with three replication of each treatment.

Observation on radial growth were measured in both nano-formulation and different plant inducer chemicals amended media and untreated control and extended of incubation of mycelia growth by each formulation was calculated by estimating the percent reduction in mean mycelia radial growth over that control (Vincent, 1947).

Inhibition $\%=\frac{c-T}{c} \times 100$

The poisoned food technique (Falck, 1907) was followed to evaluate the efficacy of chemicals, in this technique different concentrations of the test chemicals are mixed with the nutrient medium (PDA) and then test organism is allowed to grow in such medium.

Effect of different chemicals against different foliar diseases on potato crops under net house condition

Under net house condition, different chemicals were applied 1 day before spore 
inoculation and 1 day post inoculation on potato crop. Forty five days old plant of Potato, with different nano formulations and plant inducer chemicals molecule with different concentrations i.e., $25 \mathrm{ppm}$ and 50 ppm. The control is amended with sterile distilled water without any formulation with three replication of each treatment.

Spore obtained from the actively growth expanding of 7- 9 days old colony of each isolated pathogens and inoculated to plants. Observations were taken after 10 days. Disease severity calculated by scoring the diseases following 0-9 scale of Mayee and Datar (1986)

Disease Severity $(\%)=$ sum of all numerical rating

No of leaves examined XMaximum disease rating $\times 100$

The disease severity was recorded at $7,14,21$ days and 28 days after onset of disease in all tested crops.

\section{Results and Discussion}

In-vitro evaluation of chemicals against isolated foliar fungal pathogens Alternaria solani on potato

The result from the Table 1 and plate 1, it reveals that out of seven chemicals considered for the in-vitro study. $\mathrm{AgNO}_{3} @ 7.76 \mathrm{ppm}$ appeared to be most effective in respect of mycellial growth inhibition against the pathogen Alternaria solani.

It was also observed that more or less all the chemicals proved themselves to be better than check chemical Isoprothiolane (19.05 ppm). Hence, these above observations are in agreement with the previous findings of Young- ki Jo et al., 2009. They noticed that role of $\mathrm{AgNO}_{3}$ had some inhibitory effects against the microbial colony formation, disease progress by the pathogen and direct contact of silver with spore and germ-tube resulted inhibition of their viability (Fig. 1 and 2).

Table.1 Regression and correlation of toxicity of chemicals against Alternaria solani (Mycelia growth inhibition)

\begin{tabular}{|l|l|l|l|}
\hline \multirow{2}{*}{ Chemicals } & \multicolumn{2}{|l|}{ Mycellial growth inhibition(MGI) } \\
\cline { 2 - 4 } & $\begin{array}{l}\text { Regression } \\
\text { Equation }(\mathbf{R E})\end{array}$ & $\begin{array}{l}\text { Co-efficient } \\
\text { determination }\left(\mathbf{R}^{2}\right)\end{array}$ & $\begin{array}{l}\text { ED-50 } \\
(\mathbf{p p m})\end{array}$ \\
\hline Silver nanoparticle (AgNPs) & $\mathrm{y}=1.606 \mathrm{x}+3.183$ & $\mathrm{R}^{2}=0.94$ & 13.52 \\
\hline $\mathbf{H}_{\mathbf{2}} \mathbf{O}_{\mathbf{2}}$ & $\mathrm{y}=0.746 \mathrm{x}+4.178$ & $\mathrm{R}^{2}=0.849$ & 12.61 \\
\hline $\begin{array}{l}\text { Silvox } \\
\left(\mathbf{H}_{2} \mathbf{O}_{2} \text { and AgNPs) }\right.\end{array}$ & $\mathrm{y}=0.881 \mathrm{x}+3.928$ & $\mathrm{R}^{2}=0.834$ & 16.47 \\
\hline $\mathbf{C h i t o s a n}^{\text {Salicylic acid }}$ & $\mathrm{y}=0.709 \mathrm{x}+3.445$ & $\mathrm{R}^{2}=0.867$ & 17.57 \\
\hline AgNO & $\mathrm{y}=0.756 \mathrm{x}+4.037$ & $\mathrm{R}^{2}=0.743$ & 18.78 \\
\hline $\begin{array}{l}\text { Isoprothiolane } \\
\text { (check chemical) }\end{array}$ & $\mathrm{y}=1.315 \mathrm{x}+3.829$ & $\mathrm{R}^{2}=0.963$ & 7.76 \\
\hline
\end{tabular}

$\mathrm{X}=$ Probit value of percentage inhibition; $\mathrm{Y}(\mu \mathrm{g} / \mathrm{ml})=$ Antilog of the value obtained 
Fig.1 In-vitro testing of chemicals against Alternaria solani (Mycelia Growth Inhibition)

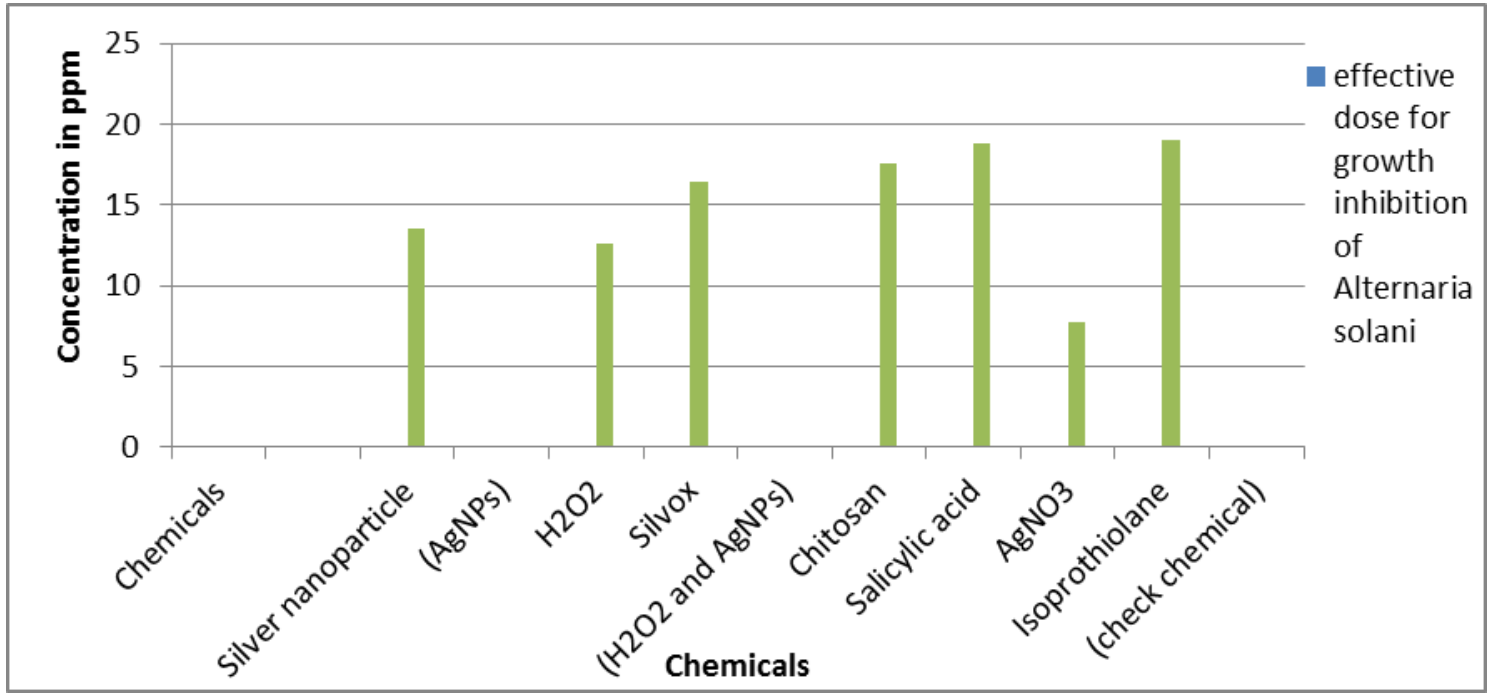

Fig.2 Probit value of percentage inhibition with log value of concentration of chemicals used in In-vitro testing against Alternaria solani
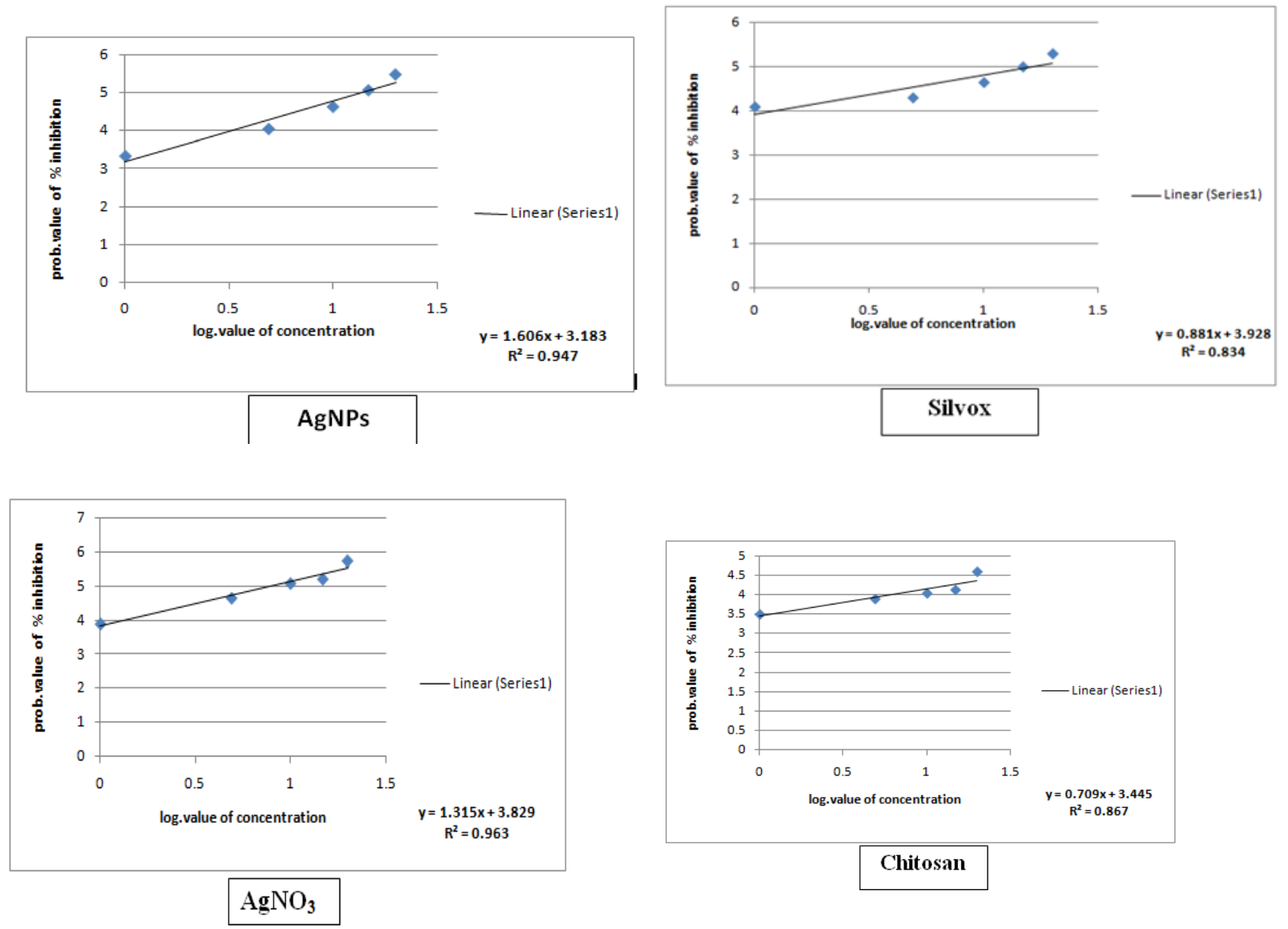

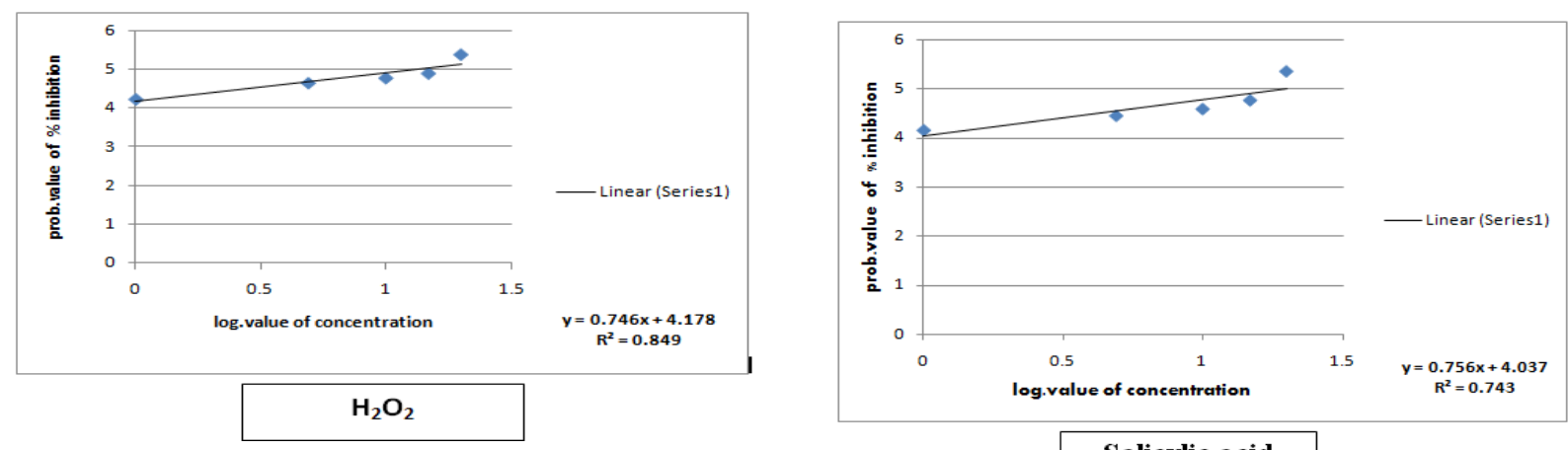

Salicylic acid

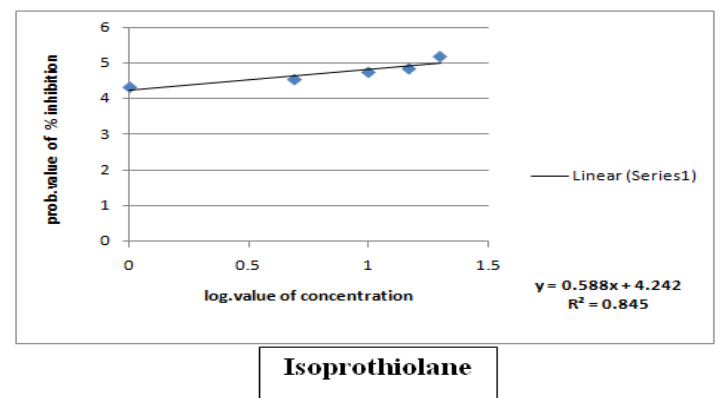

Fig.3 Efficacy of Nano and inducer chemicals against Leaf Spot causing Alternaria Solani pathogen on Potato under Net House Condition
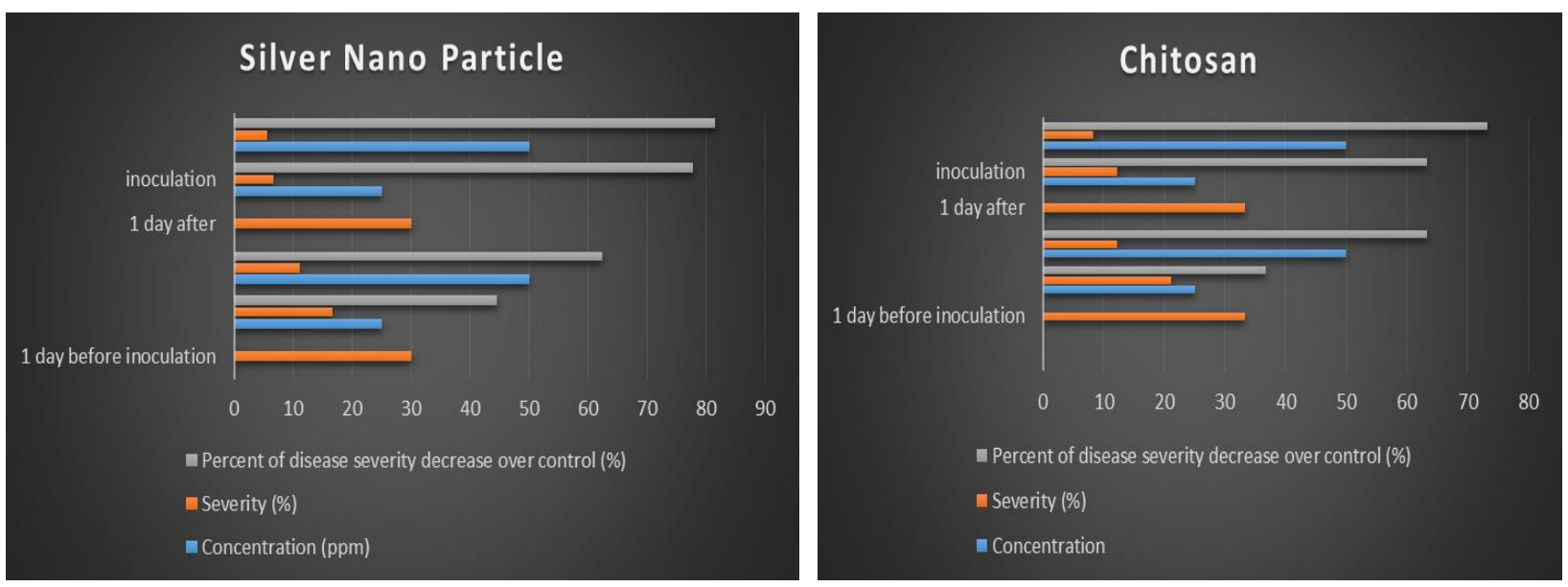


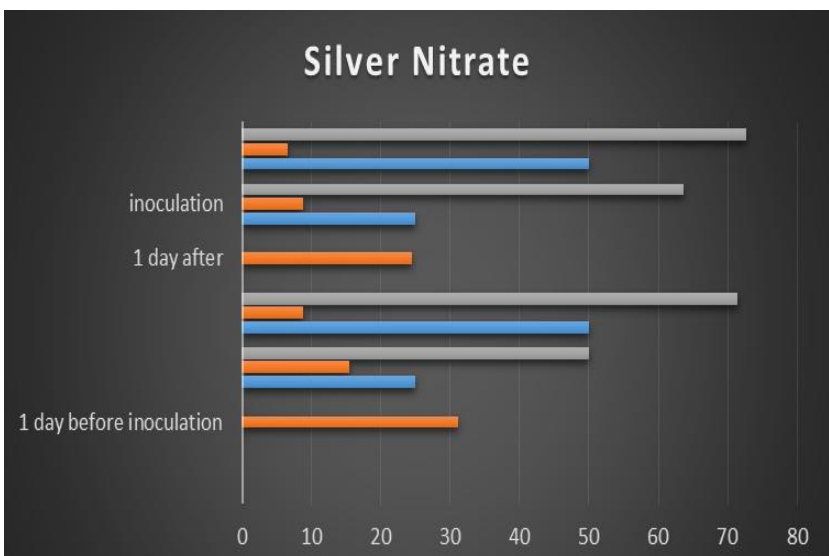

n Percent of disease severity decrease over control (\%) \# Severity (\%) \# Concentration

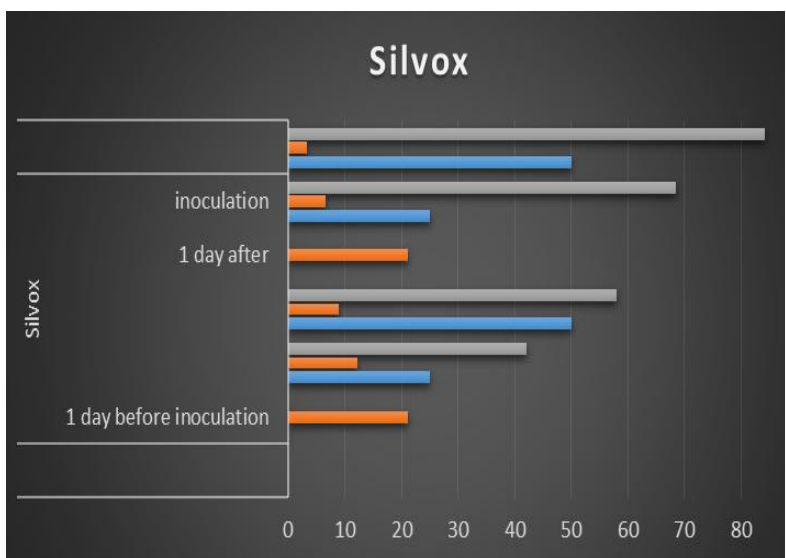

- Percent of disease severity decrease over control (\%) \# Severity (\%) n Concentratio
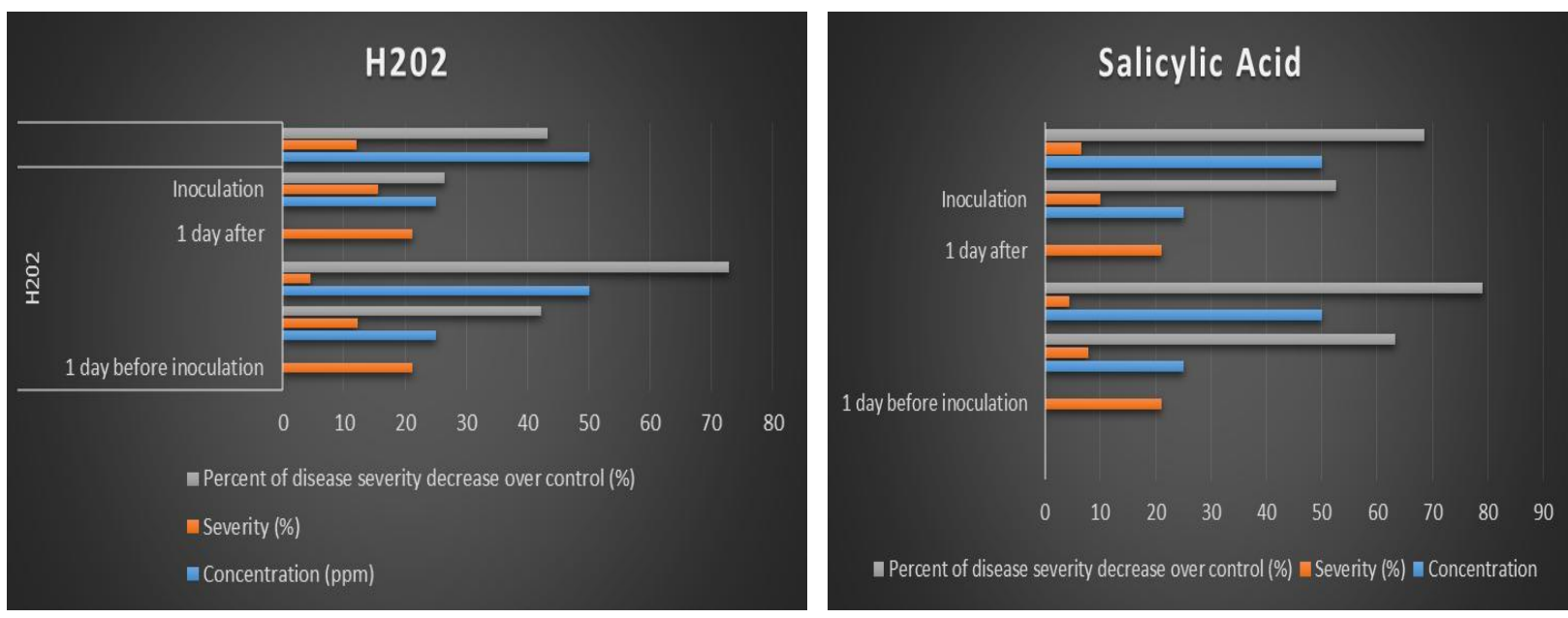

口Percent of disease severity decrease over control (\%) \# Severity (\%) n Concentration

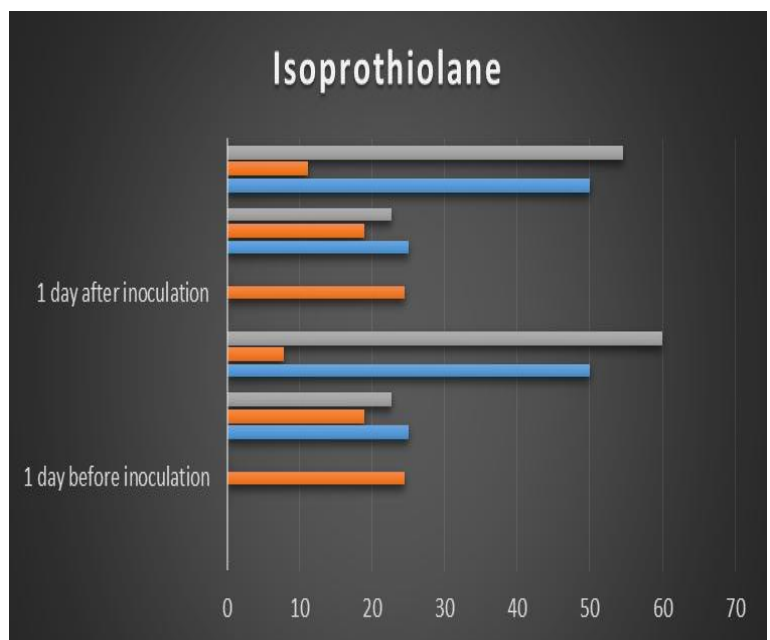

u Percent of disease severity decrease over control (\%) I Severity (\%) I Concentration 
Plate.1 In-Vitro Study of Sensitivity of Alternaria solani against 7 Different Chemicals

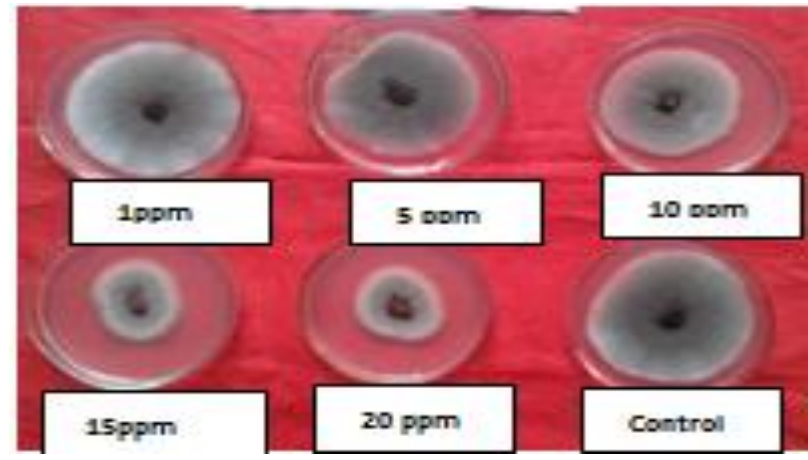

In-vitro effect of Chitosan

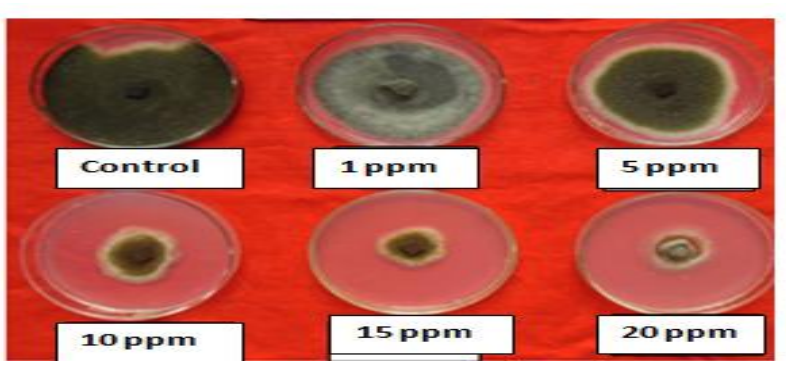

In-vitro effect of AgNPs

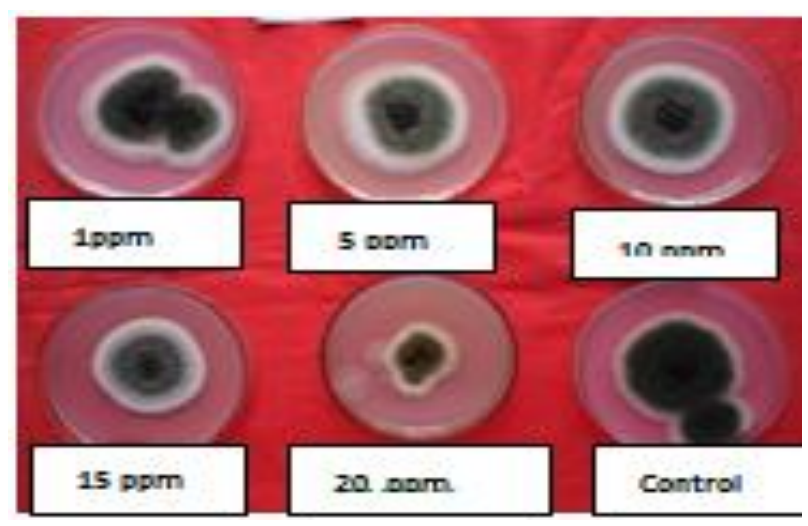

In-vitro effect of $\mathrm{H}_{2} \mathrm{O}_{2}$ :

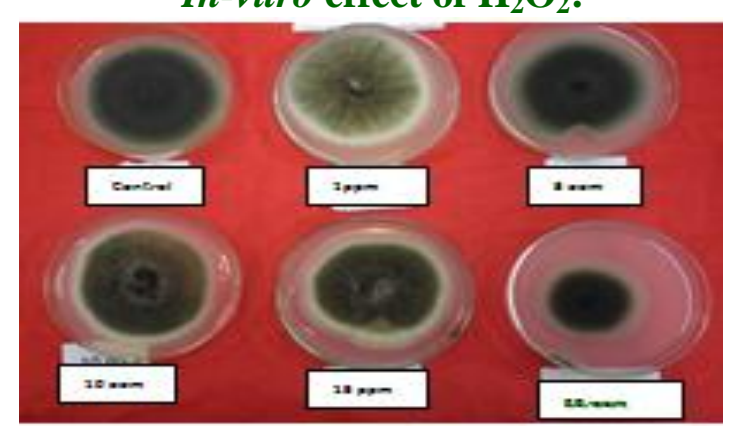

In-vitro Effect of Isoprothionale

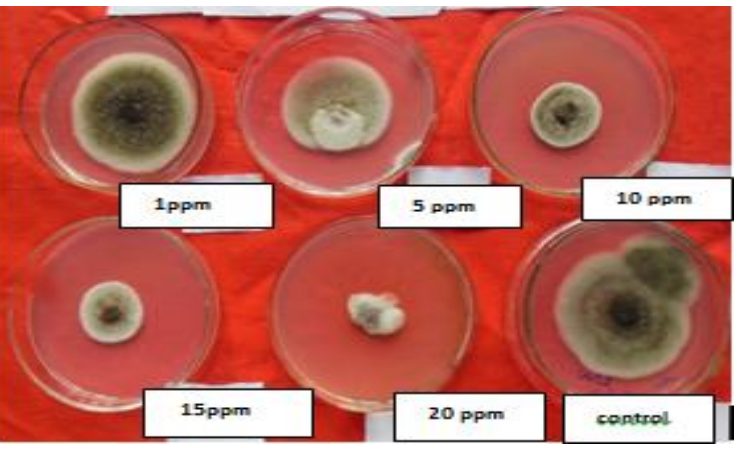

In-vitro effect of Silvox

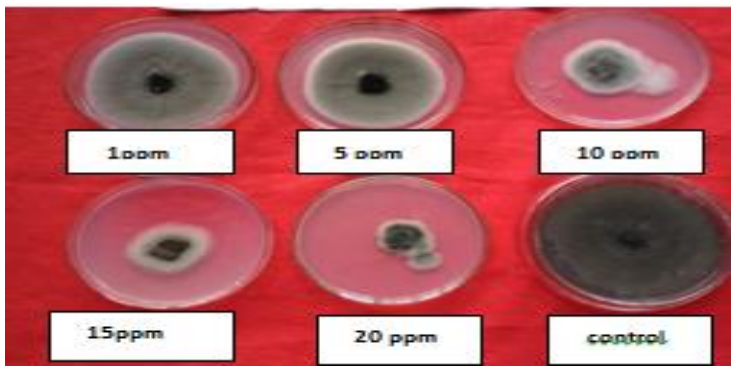

In-vitro effect of $\mathrm{AgNO}_{3}$

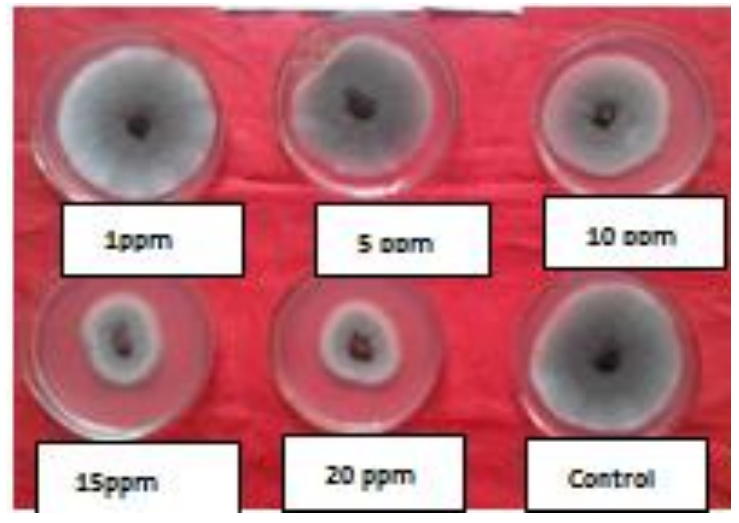

In-vitro Effect of Salicylic Acid 
From the Figure 3 it was noticed that curative application (spraying 1 day after diseases inoculation) of above mentioned nanoformulations (Silver nano-particle, Silvox, Chitosan, Silver nitrate) exhibited significant disease suppression as compared to prophylactic (spraying 1 day before diseases inoculation) application. Through curative application after onset of disease, all the nano-formulations gave significant result at 50 ppm (Silver nano-particle (AgNPs)81.50\%, $\mathrm{AgNO}_{3}-72.74 \%$, Silvox-84.22\% and Chitosan-73.33\%) applied after onset of disease. From the figure 3 inducer chemicals (salicylic acid, hydrogen-peroxide) inhibited the growth of pathogen through suppression of disease only due to prophylactic way rather than curative ones. All the chemicals gives better result than the check chemical isoprothialane.

Out of seven chemicals considered for the invitro study, $\mathrm{AgNO}_{3} @ 7.76$ ppm appeared to be most effective in respect of mycelia growth inhibition against the pathogen Alternaria solani.

The second best result was shown by $\mathrm{H}_{2} \mathrm{O}_{2}$ (12.61 ppm) followed by AgNPs (13.52 ppm) as compared to check chemical Isoprothiolane (19.05 ppm). Under net house condition, an interesting result was recorded that curative application Nano-formulations exhibited significant disease suppression as compared to prophylactic application.

The curative application of all the Nanoformulations resulted significant disease suppression at $50 \mathrm{ppm}$ (Silver Nano-particle (AgNPs)-81.50\%, $\mathrm{AgNO}_{3}-72.74 \%$, Silvox$84.22 \%$ and Chitosan-73.33\%) as compared to check chemical Isoprothiolane $(60.02 \%$ at 25 ppm). Isoprothianale strongly demonstrated promising antifungal activity and disease suppression due to development of systemic resistance.

\section{References}

Booth, C., and Sutton, B C., 1984. Fusarium pallidoroseum, the correct name for $\mathrm{F}$. semitectum. Transactions of British Mycological Society. 23, 702-704.

Chowdhry, P N., Lal, S P., Mathur, N., and Singh, D V., 2000. Manual on identification of plant pathogenic and biocontrol fungi of agricultural importance. Center of Advanced studies in Plant Pathology, Indian Agricultural Research Institute, New Delhi. 149

CIP (International Potato Centre). 1996. Major Potato Diseases, Insects, and Nematodes. ISBN- 92-9060-179-5.

Das, B H., 1998. Studies on Phomopsis in the fruit of Brinjal. An $M$ S. Thesis submitted to the Department of Plant Pathology, Bangladesh Agricultural University, Mymensingh. 33-44

Falck, R., 1907. Wachtumgesetze, wachstum Laktorehnund temperature wertderholzersterenden. Myceture. J of Biopesticide, 32, 38-39.

FAO, 2004. Agricultural data. Production and Indices Data Crop Primary.http://www.fao.org.

Gang-Su Hyon, Ken-ichi Ikeda, Naoki Hosogi, Takeshi Shinogi, and Pyoyun Park, 2010. Inhibitory Effects of Antioxidant Reagent in Reactive Oxygen Species Generation and Penetration of Appressoria of Alternaria alternate Japanese Pear Pathotype. The American Phytopathological Society 100(9):840-846.

Hausladen, H., and Leiminger, J., 2011. Disease-orientated threshold values as tool for effective early blight control. Thirteenth Euro Blight workshop.

Hawkes, J G., 1999. The economic importance of the family Solanaceae. In Solanaceae IV: Advances in Biology and Utilization. M Nee, DE Symon, RN Lester and JP Jessop (Eds). Royal 
Botanic Gardens, Kew, UK. 1-8.

Hijams, R J., 2003. The effect of climate change on global potato production. American Phytopathological Journal of Potato Research. 80, 271-280.

Luck, J., Sparkman, M., Freeman, A., Trebicki, P., Griffiths, W., Finlay, K., and Chakraborty, S., 2011. Climate change and diseases of food crops. Plant Pathology. 60(1):113-121.

Mayee, C., D and Datar, V V., 1986. Phytopathometry, Technical Bulletin-1 (Special Bulletin-3) Marathwada Agricultural University, Parbhani, Maharashtra, India. 95.

Pakdeevaraporn, P., Wasee, S., Taylor, P W J., and Mongkolporn, O., 2005.Inheritance of resistance to anthracnose caused by Colletotrichum capsici in Capsicum. Plant Breeding.
124, 206-208.

Poulos, J M., 1992. Problems and Progress of Chilli Pepper Production in the Tropics. In: Hock CB, Hong LW, Rejab M, Syed AR. (Eds). Proceedings of the Conference on Chilli Pepper Production in the Tropics, Kuala Lumpur, Malaysia. 98-129.

Sekara, A., Cebula, S., Kunicki, E., 2007.Cultivated Eggplants - Origin, Breeding Objectives and Genetic Resources, A Review. Folia Horticulturae. 19, 97-114.

Vincent, J M., 1947. Distortion of fungal hyphae in the presence of certain inhibitors. Nature.159, 850-850.

Young, K J., Byung, H K., and Jung, G., 2009. Antifungal activity of silver ions and nanoparticles on Phytopathogenic Fungi. Plant Disease 93, 1037-1043.

\section{How to cite this article:}

Jayashree Bhattacharjee, Abhinandita Sahoo, Debashre Bhattacharjee and Amitava Basu. 2017. Nano Formulations and Inducer Chemicals contains Antimicrobial Property against Alternaria Leaf Blight of Potato. Int.J.Curr.Microbiol.App.Sci. 6(12): 4320-4328. doi: https://doi.org/10.20546/ijcmas.2017.612.496 